\title{
Rozdíly v náboženské socializaci napříč generacemi Ján Mišovič
}

\section{Úvod}

Problematika náboženské socializace je v centru pozornosti celé řady zahraničních autorů, přitom se jejich prrístupy z obsahového a metodologického hlediska zcela liší. Někteří svou pozornost obracejí na průběh socializace $v$ rámci jedné konkrétní společnosti ${ }^{1}$ nebo se zaměřují na průběh osvojování si náboženství v různých zemích ${ }^{2}$. Další si všímají hlavních socializačních faktorů spojených zejména s vlivem rodičů ${ }^{3}$ jiní přistupují komplexně k okolnostem vysvětlujícím náboženskou socializaci ${ }^{4}$. Ve svých analýzách využívají kromě domácích výzkumných dat i údaje za národní celky získané z mezinárodního datového souboru International Social Survey Programme (ISSP) 2008: Religion III.

Tématika náboženské socializace začíná poutat pozornost rovněž v rámci českého odborného diskurzu ${ }^{5}$ a zájem se soustředuje na intergenerační a intragenerační transmisi náboženského vyznání v ČR i v okolních zemích.

Prezentovaný článek navazuje na dosavadní přístupy charakterizující podoby náboženskosti a nenáboženskosti české společnosti a soustředuje se na okolnosti náboženské socializace v ČR, zabývá se mírou intergeneračního přenosu náboženských představ. Cílem je posouzení podoby náboženského světonázoru v rámci české populace a trendů s tím spojených a hledání odpovědi na výzkumnou otázku, jaká je role rodičovské náboženské socializace při osvojování si náboženské víry. Při interpretaci poznatků byly využity výsledky reprezentativního šetření populace ČR realizovaného v prosinci 2015 až lednu 2016.

\section{Teoretické př́istupy $\mathrm{k}$ náboženské socializaci}

Výchozí tezí pro aplikaci socializačních procesů v oblasti náboženství v ČR představuje myšlenka „Češi jsou daleko méně ne-náboženští, než by se na první pohled zdálo“6. Většina Čechů se

1 Srov. např. Alasdair CROCKETT - David VOAS, Generations of Decline: Religious Change in 20 Century Britain, Journal of the Scientific Study of the Religion 4/2006, s. 567-584.

2 Srov. např. Tim MÜLLER - Peter SCHMIDT - Nan Dirk DE GRAFF, Which Societies Provide a Strong Religious Socialization Context? Explanations Beyond the Effects of National Religiosity, Journal of the Scientific Study of the Religion 4/2014, s. 739-759.

3 Srov. např. Richard PETTS, Paternal Religiosity and Youth Religiosity: Variations by Family Structur, Sociology of Religion 1/2015, s. $95-120$

4 Srov. např. Paul VERMEER - Jacques JANSEEN - Joep DE HART, Religious Socialization and Chuch Attendance in the Netherlands from 1997 to 2007: a Panel Study, Social Compass 3/2011, s. 371-392.

5 Srov. např. Antonín PALEČEK - Roman VIDO, Náboženské vyznání v České republice z perspektivy inter- a intragenerační transmise, Naše společnost 2/2013, s. 24-35; Antonín PALEČEK, Sekularizace z pohledu inter- a intragenerační transmise: ČR ve srovnání postkomunistických zemí střední Evropy, Naše společnost 2/2015, s. 13-26.

6 Srov. Dušan LUŽNÝ - Zdeněk R. NEŠPOR a kol., Náboženství v menšině, Praha: Malvern, 2008, s. 9. 
nehlásí k církvím, nenavštěvuje bohoslužby, neprojevuje důvěru náboženským organizacím. Na druhé straně jim však není vůbec vzdálená víra v to, co je označováno pojmem nadpřirozené síly, magie. ${ }^{7}$ Opíráme se o teorii sekularizace, která je postavena na snižování významu náboženství v životě společnosti, vyznačující se strukturální diferenciací, racionalizací, pluralizací a ztrátou dominantní integrační funkce náboženství, zkrátka změnou způsobu fungování a místa náboženství ve společnosti. ${ }^{8}$

Vymezení samotné socializace, kterou je možné charakterizovat jako proces, prostřednictvím něhož se stejné či podobné hodnoty, normy, představy, postupy, přesvědčení, praktické kroky přenášejí z jedné generace na další s cílem umožnit nastupujícím příslušníkům zúčastňovat se běžného života společnosti, je východiskem k pochopení její náboženské podoby. Socializace v nejširším slova smyslu znamená integraci jednotlivců do existující sociální struktury, přitom přenos a internalizace tvoří základní obsah tohoto procesu ${ }^{9}$.

Berger a Luckmann se zabývali nejobecnějšími okolnostmi socializace, když charakterizovali tři zprostředkující články přispívající k její realizaci. Významní druzí, zpravidla rodiče, jsou prvními činiteli, kteř́ zprostředkovávají dítěti/dětem společenskou realitu, vedou je k osvojování hodnot, rolí, norem a přibližují svět v srozumitelné podobě. Dítě se později dostává do kontaktu s dalšími dětmi, vrstevníky, se širší rodinou a okolím, rozšiřuje své poznávání sociální reality. Takové poznání je pro dítě zásadní, uvědomuje si totiž, že významy důležité pro jeho rodiče jsou pokládány za stejně závažné i pro další členy společnosti. Působení širšího okolí dítěte představuje vliv méně významných druhých. Oba autoři spojují fungování těchto činitelů v procesu internalizace s faktorem, který umožňuje pokračovat ve ztotožňování se s všeobecnými druhými, tj. se společností. Právě tyto okolnosti socializace pokládají za klíčové, protože zahrnují internalizaci společností, resp. sociální struktury. „Nejen obsah socializace, ale i míra její úspěšnosti je určována společensko-strukturními podmínkami a má společensko-strukturní důsledky. " ${ }^{10}$

Část autorů abstrahuje od širšího chápání socializace a soustřed’uje se hlavně na roli rodičů a rodiny v procesu náboženské socializace ${ }^{11}$, na důležitost náboženské homogenity obou rodičů ${ }^{12}$. Němečtí odborníci zůstávají ve svých úvahách v obecnější rovině a vnímají socializaci jako komplexní proces, odehrávající se na pozadí propojení čtyř oblastí. ${ }^{13}$ Osobnost se svými dispozicemi je východiskem celého procesu, jenž bezprostředně iniciuje jednotlivé interakce. Socializace se prakticky nepřetržitě odehrává prostřednictvím osobních kontaktů, bezprostřední komunikace tváři v tvář s jinými jednotlivci, rodiči, ve specifickém rodinném prostředí. Tyto interakce $s$ přibývajícím věkem často probíhají v konkrétních společenských institucích, jako je školka, škola, kroužky, vrstevnické skupiny, církevní komunita atd. a tvoří třetí oblast socializace. Náboženská orientace není formována pouze smýšlením a chováním rodičů, ale hlavně prostředím, $\mathrm{v}$ němž lidé žijí, jejich přáteli, vrstevnickými neformálními skupinami, učiteli a manželskými partnery ${ }^{14}$.

\footnotetext{
Tamtéž, s. 25.

8 Srov. @ Dušan LUŽNÝ, Sociologické teorie náboženství - potenciál průniků? (on-line), dostupné na: http://css2017.ff.cz./prispevky/pdf, citováno dne 24. 05. 2017.

9 Srov. např. VERMEER - JANSEEN - DE HART, Religious Socialization..., s. 371-392.

10 Srov. např. Peter L. BERGER - Thomas LUCKMANN, Sociální konstrukce reality, Brno: CDK, 1999.

11 Srov. např. Christian SMITH - Melinda DENTON, Soul Searching. The Religious and Spiritual Lives of American Teenagers, New York: Oxford University Press, 2005; Richard PETTS, Paternal Religiosity and Youth Religiosity: Variations by Family Structure, Sociology of Religion 1/2015, s. 95-120.

12 Srov. např. David HUTSEBAUT, Een zekere onzekerheid. Jongeren en geloof. Amersfoort: Acco, 1995, In: VERMEER - JANSEEN - DE HART, Religious Socialization..., s. 371-392.

13 Srov. napřr. Klaus Jürgen TILLMANN, Socializationstheorien. Eine Einführung in den Zusammenhang von Gesellshaft, Institution und Subjektwerdung, Reinbek bei Hamburg: Rowohlt, 2007.

14 Srov. např. Jonathan KELLEY, National Context, Parental Socialization, and Religious Belief in 38 Nations as of 2008: The End of National Exceptionalism?, Polish Sociological Review 3/2015, s. 295-314.
} 
Samotná společnost jako celek, která rovněž ovlivňuje proces socializace prostř̌ednictvím svých specifických ekonomických, politických, sociálních a kulturních struktur, je považována za čtvrtou oblast. Propojení mezi čtyřmi uvedenými sférami má hierarchickou povahu, což znamená, že relace na mikroúrovni, resp. $v$ prvních dvou oblastech, individuální a skupinové, jsou ovlivněné makroúrovní vytvářenou institucemi a celou společností. Oslabování tradiční náboženské výchovy dítěte společenským a kulturním rozvojem, odehrávajícím se na makroúrovni, je jedním $\mathrm{z}$ výrazů těchto vazeb ${ }^{15}$ a projevuje se např. rozšiřující se individualizací, formou morálního individualizmu jako výsledku klesající důležitosti tradiční autority ${ }^{16}$, nebo identifikací s procesem racionalizace, manifestované zvyšující se úrovní vzdělání a využívání urbanizace ${ }^{17}$. Neochota lidí zúčastňovat se náboženského života se vysvětluje fungováním právě těchto faktorů. ${ }^{18}$ Coleman prohlašuje, že rychlé ekonomické a sociální změny $\mathrm{v}$ posledních několika desetiletích vedou $\mathrm{k}$ rozdílům v myšlení a chápání mladých ve srovnání s jejich rodiči v takových oblastech, jako je práce, rodina, gender a sex ${ }^{19}$, a týká se to i oblasti náboženstvíi ${ }^{20}$. Rozsah masové kultury a intenzita jejího působení, nepředstavitelná před několika desetiletími, rovněž podporuje závěr o menším vlivu náboženství na mladou generaci ve srovnání $\mathrm{s}$ jejich rodiči, což může vést $\mathrm{v}$ religiózním prostředí $\mathrm{k}$ napětí mezi oběma generačními skupinami. ${ }^{21}$

V souvislosti s poklesem religiozity se uvažuje jak o roli věkových skupin, tak časových období. Poznatky nasvědčují tomu, že příslušnost k věkové skupině se jeví důležitější, než působení konkrétních událostí či okolností v různých dobách. ${ }^{22} \mathrm{~V}$ důsledku toho více nábožensky orientované generace jsou nahrazovány mladšími, méně nábožensky ovlivněnými skupinami. Obojí, náboženská víra i náboženská příslušnost (believing and belonging), klesají ve stejné míře zcela v rozporu s argumenty Davie ${ }^{23}$ a dalších ${ }^{24}$.

Mnohé studie náboženské socializace realizované $\mathrm{v}$ zemích s rozdílnou mírou religiozity a náboženského života dospívají k závěru, že vliv socializačního úsilí rodičů se zmenšuje a konkurují mu další socializační činitele, počínaje mimorodinným prostředím a konče ekonomickými, sociálními a kulturními změnami. Současný výsledek náboženské socializace v ČR a vývoj situace $\mathrm{v}$ tomto směru naznačí další části článku.

\section{Metodologie a data}

Domácí autoři, podobně jako někteří zahraniční, využili při analýze náboženské socializace mezinárodní údaje z roku 2008. Náš postup byl jiný a při identifikaci průběhu socializace posloužila data $\mathrm{z}$ reprezentativního šetření populace ČR 15leté a starší, ${ }^{25}$ realizovaného Klubem společenských

15 Srov. např. VERMEER - JANSEEN - DE HART, Religious Socialization..., s. 371-392.

16 Srov. např. Dick HOUTMAN - Peter MANCINI, Why Do Churches Become Empty. While New Age Grows? Secularization and Religious Change in Netherlands, Journal for the Scientific Study of Religion 3/2002, s. 455-473.

17 Srov. např. Manfred TE GROTENHUIS - Peer SCHEEPERS, Churches in Dutch: Causes of Religious Disaffiliation in The Netherlands, 1933-1955?, Journal for the Scientific Study of Religion 4/2001, s. 591-606.

18 Srov. napr. VERMEER - JANSEEN - DE HART, Religious Socialization..., s. 371-392.

19 Srov. napry. John COLEMAN, Young people in Britain at the beginning of a new century, Children and Society 4/2000, s. $230-242$.

20 Srov. např. Jan HORWATH - Janet LEES - Peter SIDEBOTHAM, The influence of religion on adolescent family life in England: an explanatory study of the views of young people and parents, Social Compass 2/2012, s. 257-275.

21 Srov. napr. Ingrid STORM - David VOAS, The Intergenerational Transmission of Religious Service Attendence, Nordic Journal of Religion and Society 2/2012, s. 131-150.

22 Srov. např. Alasdair CROCKETT - David VOAS, Generations of Decline: Religious Change in 20 Century Britain, Journal of the Scientific Study of the Religion 4/2006, s. 567-584.

23 Srov. napr. Grave DAVIE, New Approaches in the Sociology of Religion: A Western Perspective, Social Compass 1/2004, s. 73-84.

24 Srov. např. CROCKETT - VOAS, Generations of Decline..., s. 567-584.

25 Ve výzkumu byl použitý kvótní výběr pro konstrukci reprezentativního souboru, stejně jako v kontinuálních výzkumech CVVM, výzkumech agentury Median a jiných agentur pro ČT, nebo v exit pollech pro ČT. 
věd pod názvem Vliv hodnotových orientací a světového názoru na rozhodování lidí v počtu 522 respondentů. 80 tazatelů $\mathrm{z}$ proškolené sítě Klubu společenských věd uskutečnilo v průběhu prosince 2015 a ledna 2016 sběr dat, a to na základě kvótního výběru a prostřednictvím standardizovaných rozhovorů. Kontrolovanými znaky při volbě respondentů byly pohlaví, věk, vzdělání, velikost místa bydliště a region. Jeden $\mathrm{z}$ okruhů se orientoval na společenské a politické teze, související se světonázorem dotázaných a jejich každodenními životními projevy. Takto konceptualizovaný obsah umožnil prostřednictvím následujících proměnných rovněž analyzovat náboženské cítění a smýšlení a okolnosti náboženské socializace. Za indikátor náboženské víry jsme považovali odpověd na otázku: „Za jak důležitou považujete pro sebe víru v Boha? Velmi důležité, zčásti důležité, nedůležité“. Míra religiozity byla zachycena prostřednictvím souhlasu nebo nesouhlasu s výrokem: „Náboženství je spása lidstva. Souhlasím zcela, zčásti, nesouhlasím, nevím “ předloženým na lístku. Další z výroků: „V̌ěrím v nadpřirozené síly ano, vždy, ano, někdy, ne“ mapoval alternativní religiozitu dotázaných. Operacionalizovaná proměnná, týkající se představ o podstatě světa, byla formulovaná následovně: „Máte za to, že svět má materialistickou podstatu, řídí se přírodními zákony, nebo má duchovní podstatu, je ř́zen Bohem nebo jinými nadpřirozenými silami, nebo nevíte“.

Dva samostatné dotazy sledovaly stupeň náboženské orientace otce a matky dotázaných $\mathrm{v}$ následujícím znění „Dá se říct, že Váš otec byl či je, matka byla či je věřící člověk? Ano, zčásti, ne“. Komparace odpovědí na poslední dvě otázky v rámci základních věkových skupin, tedy mladé generace, mladší střední generace, starší stř̌ední generace a nejstarší generace, je východiskem pro hodnocení socializace náboženských představ, podobně jako u jiných autorư ${ }^{26}$. Víra v Boha u dotázaného a víra obou rodičů byla zjištována na celostátní úrovni i v roce 1991. Šlo o výzkum pro Československou biblickou společnost, sponzorovaný Světovou biblickou společnosti a uskutečněný v březnu 1991 v IVVM Praha. Soubor občanů ČR 15letých a starších v počtu 1961 dotázaných byl vybrán metodou kvótního výběru s kontrolovanými znaky pohlaví, věk, velikost místa bydliště, region a ekonomická aktivita. Výběr pro současný výzkum probíhal stejným způsobem a stejnými kontrolovanými znaky, s výjimkou ekonomické aktivity, která byla nahrazena vzděláním.

Hodnocení jednotlivých aspektů náboženství a míru náboženské orientace rodičů jsme spojovali s vlivem subjektivních okolností. Výsledky plynoucí ze srovnání dat v letech 1991 a 2016 mezi věkovými skupinami jsme považovali za důsledek objektivních okolností. Případy, kdy alespoň jeden $\mathrm{z}$ rodičů byl pokládán za částečně věrícího a respondent uznal víru v Boha alespoň za částečně důležitou, jsme hodnotili jako náboženský přenos. Reprodukce nevíry byla sledována ve skupině s oběma nevěrícími rodiči v návaznosti na nedůležitost víry v Boha u dotázaného. Stav, $\mathrm{v}$ němž nejméně jeden $\mathrm{z}$ rodičů byl alespoň částečně považován za věŕícího, pro samotného respondenta však víra v Boha nebyla důležitá, odrážel dekonverzi. Situací, v níž dotázaný pokládal víru v Boha za velmi či zčásti důležitou, přitom oba rodiče byli nevěříć, jsme označili jako konverzi. Určitě je potřebné upozornit na limity celé studie. První představuje šest proměnných, jež indikovaly náboženský světonázor a umožnily dílčí, orientační analýzu jednotlivých věkových skupin. Dalším limitujícím faktorem je velikost reprezentativního souboru. Přesto by námi zaznamenané tendence mohly stát za pozornost při jejich přristím možném ověření. ${ }^{27}$ Téma náboženskosti a nenáboženskosti prezentujeme v následující části.

26 Srov. napr. CROCKETT - VOAS, Generations of Decline..., s. 567-584; Joel ROBBINS, How Do Religions End? Theorizing Religious Traditions from the Point of View of How They Disappear, Cambridge Anthropology 2/2014, s. 2-15.

27 Pro ilustraci, zastoupení jednotlivých věkových skupin bylo následující: 15-29 let $22 \%$ a zbývající tři věkové skupiny po $26 \%$. Daleko nerovnoměrnější rozdělení podsouborů využívají běžně pro publikační účely zahraniční autoři. Např. Hunsberger, Pratt a Pancer v článku Religious Versus Nonreligious Socialization: Does Religious Background Have Implication for Adjustment?, The International Journal for the Psychology of Religion 2/2001, s. 105-128. V článku je analyzovaný soubor N=615 s následujícím členstvím respondentů v církvích $28 \%, 8 \%, 52 \%, 12 \%$. 


\section{Rozšíření náboženských a nenáboženských pohledů na svět}

Jedním ze záměrů studie je charakterizovat současné rozšiřrení náboženského světonázoru v ČR a v návaznosti na to přiblí̌̌it okolnosti náboženské socializace, míru generačního přenosu náboženských a nenáboženských myšlenek a pohledů. Interpretace bloku otázek, indikujících religiozitu v rámci populace ČR a jednotlivých věkových skupin, se nám jeví jako nejefektivnější. Úvodem rozložení jednotlivých stránek náboženské orientace.

Tabulka 1: Výpovědi populace ČR a základních věkových skupin o své náboženské orientaci (v\%)

\begin{tabular}{|lllllll|}
\hline & & ČR & $15-29$ let & $30-44$ let & $45-59$ let & $60+$ \\
Věří v nadpřirozené síly & Vždy & 11 & 9 & 17 & 12 & 7 \\
& Někdy & 21 & 32 & 19 & 25 & 21 \\
& Nikdy & 68 & 59 & 64 & 63 & 72 \\
& & & & & & \\
Víra v Boha je pro dotázaného & Velmi důležitá & 10 & 6 & 10 & 13 & 10 \\
& Zčásti důležitá & 15 & 19 & 18 & 21 & 21 \\
& Nedůležitá & 75 & 75 & 72 & 66 & 69 \\
& & & & & & \\
Náboženství je spása lidstva & Souhlasí & 7 & 5 & 7 & 10 & 5 \\
& Zčásti souhlasí & 10 & 9 & 11 & 10 & 10 \\
& Nesouhlasí & 70 & 67 & 69 & 65 & 76 \\
& Neví & 13 & 19 & 13 & 15 & 9 \\
\hline
\end{tabular}

Zdroj: Výzkum Vliv hodnotových orientací.

Respondenti se vyjadřovali ke třem stránkám náboženské orientace - $\mathrm{k}$ víře $\mathrm{v}$ Boha, $\mathrm{k}$ důležitosti náboženství pro lidstvo a obecně k uznání nadpřirozených sil. Víra v nadpřirozené síly je nejrozšiřenější, je vnímána prakticky třetinou obyvatel. Alespoň někdy v ně věří kolem dvou pětin mladých do 29 let, ale jen o něco více než čtvrtina 60letých a starších. Situace je odlišná z hlediska víry v Boha. Nejmenší počet souhlasných a nejvíce odmítavých odpovědí je mezi mladou generací. Pro někoho může být překvapivé, že starší střední generace představuje věkovou skupinu s největší důležitostí víry v Boha a současně relativně s nejnižším nesouhlasem. Třetina 45-59letých přikládá víře v Boha větší či menší důležitost.

Výraz vztahu k institucionalizovaným formám náboženství představuje odpověd' na otázku po roli náboženství při spáse lidstva. Nejméně souhlasných a nejvíce nesouhlasných odpovědí zaznívá od př́íslušníků nejstarší generace 60letých a starších. V případě této věkové skupiny jde $s$ největší pravděpodobností o vliv předlistopadové protináboženské propagandy. Příslušníci další nejbližší věkové kohorty 45-59 let mají naopak mezi sebou nejvíce stoupenců významu náboženství (desetinu) a rovněž nejméně nesouhlasících (necelé dvě třetiny). Tato skupina tvořila po roce 1989 podstatnou část nastupující mladé generace a její postoje se utvářely na základě volného působení náboženství, tedy nejen vlivem protináboženských aktivit předchozího režimu.

Doplňující pohled na náboženské názory poskytují odpovědi na otázku po podstatě světa, uvedené v tabulce 2 . 
Tabulka 2: Názory na podstatu světa populace ČR a základních věkových skupin (v \%)

\begin{tabular}{|llllll|}
\hline Svět má podstatu & ČR & $15-29$ let & $30-44$ let & $45-59$ let & $60+$ \\
Materialistickou & 56 & 45 & 59 & 57 & 61 \\
Duchovní, je řízen Bohem & 6 & 5 & 6 & 10 & 4 \\
Má jinou podstatu & 3 & 5 & 5 & 2 & 2 \\
Neví, neodpověděl & 35 & 45 & 30 & 31 & 33 \\
\hline
\end{tabular}

Zdroj: Výzkum Vliv hodnotových orientací.

Materialistický pohled na svět převažuje $\mathrm{v}$ české populaci $\mathrm{s}$ více než polovičním podílem. $\mathrm{V}$ jednotlivých věkových skupinách však panují rozdíly. Diference podle věku v rámci předchozích odpovědí se potvrzují i prostřednictvím uvedených zjištění. Lidé starší stř̌ední generace nejčastěji zastávají náboženské představy. Nejmladší respondenti do 29 let se nejméně hlásí k materialistické podstatě světa a nejčastěji se nedokázali orientovat. Deklarovaný materialistický či náboženský pohled na podstatu světa ještě neznamená vždy jednoznačný názor. Podrobnější analýzy ilustrují, že materialistický pohled na svět a současně nedůležitost víry v Boha zastává $44 \%$ dotázaných. $\mathrm{K}$ důležitosti víry v Boha a $\mathrm{k}$ duchovní podstatě světa se hlásí $5 \%$. Zbývajících $51 \%$ se vyznačuje větším či menším prolínáním obou stanovisek.

Časová komparace víry v Boha v rámci jednotlivých hlavních věkových skupin se zatím v domácí literatuře neobjevila. Možnost nabízejí údaje $\mathrm{z}$ výzkumu o vztahu populace $\mathrm{k}$ náboženství, víre a Bibli z roku 1991, kde se rovněž zjištovala i víra v Boha. Jak dopadá srovnání odpovědi „věřím v Boha"v roce 1991 a velké důležitosti víry v Boha v roce 2016 naznačí tabulka č. 3.

Tabulka 3: Víra v Boha a velká důležitost víry v Boha ve věkových skupinách v letech 1991 a 2016 (v \%)

\begin{tabular}{|llllll|}
\hline & ČR & $15-29$ let & $30-44$ let & $45-59$ let & $60+$ \\
1991 & 25 & 14 & 20 & 27 & 43 \\
2016 & 10 & 6 & 10 & 13 & 10 \\
\hline
\end{tabular}

Zdroj: Výzkum Vliv hodnotových orientací a výzkum O vztahu čs. populace. (Dopočet do $100 \%$ v každém poli jsou ostatní odpovědi.)

Údaje v tabulce je možné zhodnotit ze dvou hledisek: a) porovnat rozdíly mezi věkovými skupinami za každé zjištované období, b) analyzovat výpovědi $\mathrm{v}$ čase $\mathrm{v}$ rámci jednotlivých věkových skupin.

Rovnoměrné diference $\mathrm{v}$ rozsahu 6-7 procentních bodů byly mezi třemi věkovými skupinami v prvním šetření, tedy v roce 1991. Šlo o dotázané s datem narození mezi lety 1932 a 1962 . Nejvíce věrících se objevilo ve skupině narozených v roce 1931 a dřive. 16 procentních bodů tvořil odstup od předchozí generace a od nejmladších 29 procentních bodů, nejstarší byli tedy nejčastěji věřící. Dopad náboženské výchovy byl u této generace silnější než vliv protináboženské propagandy.

Dotázaní $\mathrm{z}$ druhé nejstarší věkové skupiny tvořili v roce 2016 skupinu nejvíce věŕících a $\mathrm{z}$ hlediska počtu věŕících předstihli nejstarší generaci. Ovšem rozdíl v důležitosti víry mezi touto a nejmladší věkovou skupinou tvořilo jen 7 procentních bodů. $V$ průběhu 25 let se tedy odehrála jakási náboženská „homogenizace" ve všech věkových skupinách. 
Druhé hledisko vypovídá o reakcích stejných generací ve dvou různých časových údobích. Rozdíly mezi generačními skupinami se za hodnocené období zvyšují s přibývajícím věkem. Zastoupení víry mladých lidí mezi léty 1991 a 2016 se liší o 8 procentních bodů, v okruhu nejstarších generací je to 33 procentních bodů. Znamená to, že se společenské okolnosti za posledních 25 let podepisují na každé z věkových skupin jiným způsobem, nejrazantněji na nejstarší generaci.

Komparace věkových skupin za roky 1991 a 2016 nabízí pohled na roli systémových okolností při formování náboženské orientace, resp. objektivních podmínek náboženské socializace.

\section{K průběhu náboženské socializace}

Předchozí téma objektivních podmínek náboženské socializace doplníme charakteristikou zázemí pro rodinnou náboženskou socializaci. Předpoklady náboženské socializace byly ve výzkumu sledovány prostřednictvím výpovědi o víre každého rodiče zvlášt. Postup interpretace bude stejný jako $v$ předchozí části, analyzujeme odpovědi v celé populaci a následně v jednotlivých věkových skupinách. Data, dle našeho názoru, naznačují podmínky primární náboženské socializace pro jednotlivé generace.

Tabulka 4: Výpovědi občanů ČR a základních věkových skupin o stupni víry svých rodičů (v \%)

\begin{tabular}{|c|c|c|c|c|c|c|}
\hline & & ČR & $\begin{array}{l}15-29 \\
\text { let }\end{array}$ & $\begin{array}{l}30-44 \\
\text { let }\end{array}$ & $\begin{array}{l}45-59 \\
\text { let }\end{array}$ & $60+$ \\
\hline Matka je/byla věřící & $\begin{array}{l}\text { Ano } \\
\text { Zčásti } \\
\mathrm{Ne}\end{array}$ & $\begin{array}{l}19 \\
26 \\
55\end{array}$ & $\begin{array}{l}13 \\
26 \\
61\end{array}$ & $\begin{array}{l}12 \\
22 \\
66\end{array}$ & $\begin{array}{l}21 \\
31 \\
48\end{array}$ & $\begin{array}{l}29 \\
25 \\
46\end{array}$ \\
\hline Otec je/byl věřící & $\begin{array}{l}\text { Ano } \\
\text { Zčásti } \\
\mathrm{Ne}\end{array}$ & $\begin{array}{l}11 \\
17 \\
72\end{array}$ & $\begin{array}{l}8 \\
18 \\
74\end{array}$ & $\begin{array}{l}10 \\
15 \\
75\end{array}$ & $\begin{array}{l}13 \\
16 \\
71\end{array}$ & $\begin{array}{l}14 \\
18 \\
68\end{array}$ \\
\hline Oba rodiče jsou/byli věřící & $\begin{array}{l}\text { Ano } \\
\text { Zčásti } \\
\mathrm{Ne}\end{array}$ & $\begin{array}{l}7,3 \\
38,7 \\
54\end{array}$ & $\begin{array}{l}5,5 \\
44 \\
50,5\end{array}$ & $\begin{array}{l}4,4 \\
35 \\
60,6\end{array}$ & $\begin{array}{l}9,2 \\
47,3 \\
43,5\end{array}$ & $\begin{array}{l}10,3 \\
47 \\
42,7\end{array}$ \\
\hline
\end{tabular}

Zdroj: Výzkum Vliv hodnotových orientací.

Prakticky každý pátý dotázaný z našich respondentů má nebo měl zcela věřící matku. $\mathrm{V}$ populaci ČR je více než polovina neveřících matek. Př́slušníci mladší stř̌ední generace vypovídají o relativně nejmenším zastoupení věřících matek, současně uvádějí i nejvyšší počet neveřících matek. Počet věrících matek $\mathrm{v}$ dalších věkových skupinách přibývá a zároveň klesá podíl nevěrících. Je jen přirozené, že nejvýrazněǰsí zastoupení věřících a nejnižší podíl nevěrících matek je v okruhu nejstarší generace. „Zvláštní část tvoří matky nejmladších respondentů. Provedeme-li srovnání s nejbližší věkovou skupinou, potom podíl věřících matek je vyšší o 1 procentní bod a o 5 procentních bodů je nižší zastoupení nevěřících matek. I když nejde o statisticky významné rozdíly vzhledem k velikosti souboru, údaje mohou signalizovat změny, které se odehrávají ve vnímání víry a náboženství i v rodičovských generacích. 
Podíl věřících otců je celkově nižší než věřících matek. Každý devátý otec patří do okruhu věřících a téměř tři čtvrtiny do kategorie nevěřících. Zastoupení věřících otců se zvyšuje se stoupajícím věkem respondentů, avšak nijak výrazně (celkem o 6 procentních bodů). Největší počet nevěřících otců má věková skupina 30-44 let (tři čtvrtiny). Starší generace jich mají méně. Zastoupení nevěřících otců je v okruhu mladých lidí do 29 let o 1 procentní bod nižší než v následující věkové kohortě. Drobný rozdíl může naznačovat změnu dosavadního trendu v náhledu na spirituální dimenzi života člověka v prostředí starší střední rodičovské generace. Diference v dưležitosti víry dotázaného a víry matky a otce ilustrují větší blízkost k víře otce než matky.

Při bližším pohledu na totožnost víry obou rodičů je zřejmé, že nábožensky orientovaných rodin v ČR je $7 \%$, nenábožensky zaměřených více než polovina (54 \%) a alespoň částečně nábožensky směřovaných prakticky dvě pětiny (39\%). Je možné zopakovat, že nejméně náboženští (4\%) a nejvíce nenáboženští (61 \%) jsou rodiče mladší střední generace 30-44letých, tedy lidé ve věku 60 let a starší, přitom tato generace má nebo měla rodiče nejvíce nábožensky orientované.

Opětovně se potvrzuje, že mezi rodiči nejmladších respondentů je o 1 procentní bod více věřících než $\mathrm{v}$ okruhu rodičů $\mathrm{v}$ následující věkové skupině a současně o 10 procentních bodů méně nevěřících.

Nabízí se jedno z dalších srovnání, možnost komparace víry rodičů v roce 1991 a 2016 s velkou důležitostí víry v Boha samotných dotázaných. Následující tabulka přináší porovnání víry dotázaného a jeho matky ve věkových skupinách v uvedených letech.

Tabulka 5 Víra v Boha u matky v letech 1991, 2016 a velká důležitost víry v Boha u dotázaného 2016 (v \%)

\begin{tabular}{|lllll|}
\hline & $15-29$ let & $30-44$ let & $45-59$ let & $60+$ \\
Věřící matky 1991 & 23 & 42 & 55 & 69 \\
Věŕící matky 2016 & 13 & 12 & 21 & 29 \\
Věŕící dotázaní 2016 & 6 & 10 & 13 & 10 \\
\hline
\end{tabular}

Zdroj: Výzkum Vliv hodnotových orientací a výzkum O vztahu čs. populace. ${ }^{28}$ (Dopočet do $100 \%$ v každém poli představují ostatní odpovědi.)

Rozdíly mezi vírou dotázaných a jejich matek v jednotlivých věkových skupinách a také mezi vírou matek s pětadvacetiletým časovým odstupem naznačuje tabulka. Dnešní mladá generace se ve víře v Boha liší od svých matek o 7 procentních bodů, mladší střední generace o 2 procentní body, starší střední generace o 8 procentních bodů a nejstarší o 19 procentních bodů. Rozdíly mezi 60letými a staršími dotázanými a jejich matkami jsou tedy nejvýraznější.

Postupný nárůst diferencí byl zaznamenán při zkoumání podílu věřících matek v jednotlivých generacích dnes a před 25 lety. Nejmenší nerovnosti panují v generacích nejmladších matek (o 10 procentních bodů) a naopak nejvýraznější mezi generačně nejstaršími (o 40 procentních bodů). Změny týkající se víry dotázaného a víry otce jsou uvedeny analogicky. Údaje přiblíží tabulka č.5.

28 Srov. Ján MIŠOVIČ a kol., O vztahu čs. populace k náboženství a k Bibli, Praha: IVVM, 1991, s. 9; Ján MIŠOVIČ, Víra v dějinách zemí Koruny české, Praha: Sociologické nakladatelství, 2001, s. 130. 
Tabulka 6: Víra v Boha u otce v letech 1991, 2016 a velká důležitost víry v Boha dotázaného 2016 (v \%)

\begin{tabular}{|lllll|}
\hline & $15-29$ let & $30-44$ let & $45-59$ let & $60+$ \\
\hline Věřící otcové 1991 & 17 & 23 & 34 & 54 \\
Věrící otcové 2016 & 8 & 10 & 13 & 14 \\
Věřící dotázaní 2016 & 6 & 10 & 13 & 10 \\
\hline
\end{tabular}

Zdroj: Výzkum Vliv hodnotových orientací a výzkum O vztahu čs. populace. (Dopočet do $100 \%$ v každém poli predstavují ostatní odpovědi.)

Víra dnešních dotázaných vykazuje menší rozdíly vůči viře svých otců než vůči víře matek. Rozdíl 2 procentních bodů je $\mathrm{v}$ nejmladší věkové skupině, $\mathrm{v}$ dalších dvou věkových kohortách jsou hodnoty totožné a $\mathrm{v}$ nejstarší věkové skupině je rozdíl 4 procentních bodů.

Diference mezi roky 1991 a 2016 mezi věkovými kategoriemi ovšem s přibývajícím věkem dotázaných narůstají. V nejmladších generacích došlo za 25 let $\mathrm{k}$ poklesu víry u otců o 9 procentních bodů, zatímco u generace 60letých a starších o 40 procentních bodů.

$\mathrm{K}$ dokreslení zjištěných diferencí předkládáme výsledky faktorové analýzy, s doposud použitými šesti proměnnými, metodou PC hlavních komponent. Výsledky přináší tabulka č. 7.

Tabulka 7: Váha jednotlivých faktorů v náboženské světonázorové orientaci

\begin{tabular}{|c|c|c|c|c|c|}
\hline Zkoumané položky & Extrakce & Komponenty & Total & $\%$ variace & Kumulativní \% \\
\hline $\begin{array}{l}\text { 1. Za jak důležité považuje } \\
\text { víru v Boha }\end{array}$ & .694 & 1. & 2.26 & 42.61 & 42.61 \\
\hline 2. Otec byl/je verřící & .690 & 2. & 1.06 & 17.70 & 60.31 \\
\hline $\begin{array}{l}\text { 3. Náboženství je spása lid- } \\
\text { stva }\end{array}$ & .652 & 3. & .98 & 16.27 & 75.58 \\
\hline 4. Matka byla/je věřící & .631 & 4. & .55 & 9.20 & 85.78 \\
\hline 5. Věřím v nadpřirozené síly & .467 & 5. & .44 & 7.40 & 93.18 \\
\hline 6. Má/nemá světový názor & .484 & 6. & .41 & 6.82 & 100.00 \\
\hline
\end{tabular}

Zdroj: Výzkum Vliv hodnotových orientací.

Dvě nejsilnější komponenty, vysvětlující celkem 60 \% rozptylu hodnot šesti proměnných, se ukázaly jako nejpodstatnější. Těmi dvěma proměnnými jsou důležitost víry dotázaného a víra otce.

Poslední údaje se budou týkat náboženského přenosu mezi rodiči a dětmi v podobě náboženské a nenáboženské reprodukce, dekonverze a konverze v jednotlivých věkových skupinách. 
Tabulka 8: Vztah víry rodičů a víry dotázaných podle věkových skupin (v \%)

\begin{tabular}{|lllll|}
\hline & $\begin{array}{l}\text { Reprodukce } \\
\text { víry }\end{array}$ & $\begin{array}{l}\text { Reprodukce } \\
\text { nevíry }\end{array}$ & dekonverze & konverze \\
ČR & 24 & 45 & 25 & 6 \\
$15-29$ let & 21 & 53 & 22 & 4 \\
$30-44$ let & 20 & 51 & 20 & 9 \\
$45-59$ let & 27 & 37 & 29 & 7 \\
$60+$ & 28 & 41 & 29 & 2 \\
\hline
\end{tabular}

Zdroj: Výzkum Vliv hodnotových orientací.

Ti, kteři víceméně přebírají víru obou svých rodičů, tvoří v populaci ČR necelou čtvrtinu, více než dvě pětiny nevěří stejně jako jejich rodiče, od náboženské víry rodičů se odklání čtvrtina dotázaných a $6 \%$ dnešních alespoň částečně věřících v Boha bylo vychováno nevěřícími rodiči. ${ }^{29}$

Trendy, které se objevovaly v předchozích zjištěních, se projevily i ve výše uvedené tabulce. Reprodukce víry probíhá ve dvou mladších věkových skupinách u pětiny dotázaných, u dvou starších věkových skupin pozorujeme transmisi u více než čtvrtiny. Rozdíl mezi věkovými skupinami s nejnižší a nejvyšší mírou reprodukce je 8 procentních bodů.

Reprodukce nevíry je nejvýraznější ve věkové skupině 15-29 let, týká se více než poloviny všech $\mathrm{z}$ této části. Podobné je to i v kategorii mladší střední generace. Nevěřící se reprodukují nejméně mezi starší stř̌ední generaci (z necelých dvou pětin).

Podíl dekonvertovaných je nižší v mladších věkových kategoriích (kolem pětiny) a vyšší u starších (blíží se k třetině). Lužný tento proces ilustruje na výsledcích kvalitativního výzkumu v České Lípě a v Mikulově. Ačkoliv se do České Lípy nastěhovalo velké množství lidí pocházejících ze silně náboženských slovenských regionů, tito lidé se nezapojili do místního náboženského života. Mladí lidé z Mikulova naopak ztrácejí svůj původní náboženský zájem poté, co odcházejí ze svého bydliště, aby získali vzdělání, práci. V novém prostředí neměli zájem včlenit se do náboženského života. Možná se objevuje trend, který Lužný nazývá lhostejností a nezájmem, tedy stavem, jenž je „možná ještě varovnější, než kdyby převažovaly negativní postoje k tradičnímu náboženstvi“"30. Náboženská konverze probíhá velmi nerovnoměrně. Nejnižší je mezi 60letými a staršími. Druhý nejnižší podíl konvertovaných zaznamenáváme mezi nejmladšími. Nejvíce konvertují příslušníci mladší střední generace ve věku 30-44 let, téměř desetina z nich (9\%). Ve starší střední generaci dochází častěji ke konverzi než v nejstarší a nejmladší věkové skupině.

\section{Zamyšlení nad výsledky}

Česká republika je doposud považována za jednu z nejvíce sekularizovaných zemí. To dokumentuje řada empirických údajů. ${ }^{31}$ Ze zkoumaných náboženských projevů zaujímá víra v nadpřiro-

29 Podle údajů za ČR z výzkumu ISSP 2008 a jiného způsobu výpočtu byla míra intergenerační dekonverze 16 procentních bodů, konverze 1 procentní bod, intragenerační dekonverze 11 procentních bodů a konverze 1 procentní bod. Srov. Antonín PALEČEK, Sekularizace z pohledu inter a intragenerační transmise: ČR ve srovnání postkomunistických zemí stř̌ední Evropy, Naše společnost 2/2015, s. 13-26.

30 Srov. LUŽNÝ - NEŠPOR a kol., Náboženství..., s. 198-199.

31 Vyplývá to i z analýzy údajů ISSP 2008, když při porovnání regresního koeficientu zachycujícího efekt vlivu návštěvnosti bohoslužeb rodičů na náboženskou víru respondenta z 38 zemí je na prvním místě Turecko s hodnotou 0,0005 a na posledním místě ČR s koeficientem 0,0097. Stejný stav vládne při porovnání průměru náboženské víry (první Turecko 0.95, poslední ČR 0.32). Srov. KELLEY, National Context..., s. 295-314. 
zené síly nejzřetelnější pozici. Prakticky třetina populace uznává jejich pưsobení. Mladší věkové skupiny - více než starší - vě̌í v tyto síly častěji než v Boha. $Z$ okruhu mladých lidí jsou to více než dvě pětiny, ${ }^{32} \mathrm{z}$ mladší stř̌ední generace do 44 let více než třetina. Starší stř̌ední generace, která po roce 1990 patřila do skupiny mládeže, má ve svém středu největší část těch, pro které je víra v Boha zčásti nebo velmi důležitá a rovněž nejčastěji oceňuje roli náboženství pro lidstvo. Nejstarší respondenti, zahrnující narozené v roce 1956 a dříve, představují generaci, pro níž jsou všechny zkoumané aspekty náboženství nejméně důležité a postojově se více blíží k mladším generacím. Získané poznatky o generacích určitým způsobem korespondují se zjištěními z kvalitativního výzkumu náboženského života na Hlučínsku. „Někteří př́íslušníci první generace soudí, že zatímco jejich děti (druhá generace) do kostela moc nechodí a víru v podstatě nepraktikují, jejich vnoučata, tedy př́slušníci třetí generace, se $\mathrm{k}$ víře vracejí. “33

Časové srovnání víry dotázaných a víry rodičů za uplynulých 25 let umožnilo sledovat, do jaké míry dnešní náboženskou orientaci ovlivnily poměry předlistopadového režimu a jak situace spojená s obnovou kapitalismu a pluralitní demokracie. Komparace stejných generačních skupin před 25 lety a dnes naznačuje, že právě v kategorii nejstarších došlo $k$ největšímu poklesu důležitosti víry v Boha (o 33 procentních bodů). V roce 1991 byly rozdíly mezi krajními věkovými skupinami 29 procentních bodů, dnes je to 7 procentních bodů. Hranice důležitosti víry se v chápání věkových skupin za zkoumané období stírají, věkové kohorty se v tomto směru homogenizují. Tím, že došlo ke generační obměně, se podíl věřících mezi nejstaršími vyrovnal s věrííími v ostatních věkových skupinách. Jedna výrazná změna nastala oproti minulým letům, nejstarší respondenti dnes nepatř́ k nejvíce věřícím, tuto pozici převzala totiž starší střední generace do 59 let.

Víra rodičů nabízí doplňující pohled na generační zázemí respondentů. Podíl celkově a částečně věrících rodičů ve věkovém rozmezí od mladých lidí až po starší stř̌ední generace stoupá ze $47 \%$ na $63 \%$. V okruhu 60letých a starších je jich 59 \%. Tato skutečnost měla rozdílný vliv na náboženskou orientaci, jak ilustrovaly předchozí výsledky. V nejmladší věkové skupině dochází $k$ nejvýraznější reprodukci nevíry. Mladší stř̌ední generace relativně nejčastěji konvertuje. V prostř̌edí starší střední generace se nejméně často reprodukuje nevíra, ale podíl dekonvertujících je vyšší než u mladších věkových skupin. Mezi nejstaršími respondenty se nejčastěji reprodukovala víra, ale nejméně často dochází ke konverzi.

Získané výsledky z hlediska dnešní doby patrně nedávají př́liš za pravdu názoru Nešpora, podle něhož $\mathrm{v}$ české společnosti jako $\mathrm{v}$ celku skončil komunistický boj proti náboženství mezi lety 1948-1989 v podstatě úspěchem, odcírkevňováním. ${ }^{34}$ Určitě lze o úspěchu hovořit u dnešní generace 60letých a starších, ale další převážná část populace je jen částečně ovlivněna protináboženskými aktivitami před rokem 1989 nebo není ovlivněna vůbec. Údaje dokonce naznačují, že poslední generace, která zažila „tažení proti náboženství, se obrátila spíše k víře v nadpřirozeno než k církevnímu náboženství, stejně jako mladá generace narozená po roce 1987. Z logiky této komparace by vyplývalo, že i současný společenský systém odcírkevňuje, i když se neprojevuje př́mými protináboženskými prvky. Na základě uvedených poznatků je možné na výzkumnou otázku odpovědět následovně: $\mathrm{V}$ procesu náboženské socializace je rodičovská náboženská socializace sice primární, ale další faktory představované širším okolím, celou společností hrály

32 Nejen podle získaných údajů, ale i podle poznatků Hamplové inklinují k „alternativní religiozitě lidé mladší. Srov. Dana HAMPLOVÁ, Čemu Češi věrí: dimenze soudobé české religiozity, Sociologický časopis 4/2008, s. 703-724.

33 V souvislosti s charakteristikou tří generací není uveden věk, jenom vzdělání, profesní zařazení a rodinný stav, přesto lze soudit, že v našem členění jde o starší stř̌ední generaci, mladší střední a nejmladší generaci. Srov. Helena KUBÁTOVÁ a kol., Mezigenerační proměny způsobu života na Hlučínsku, Praha: Sociologické nakladatelství, 2015.

34 Srov. např. Zdeněk R. NEŠPOR, Př́liš slabí ve viře, Praha: Kalich, 2010. 
v minulých desetiletích a hrají i v současných společenských podmínkách rozhodující roli.

\section{Závěrem}

V české společnosti platí stejné mechanismy náboženské socializace jako v jiných částech Evropy. Autoři zabývající se náboženskou situací ve světě konstatují, že dnes už neexistují žádné rozdíly z hlediska náboženské výjimečnosti. Vyplývá to i ze skutečnosti, že dlouhotrvající snaha komunistických systémů bojovat proti náboženství mohla ovlivnit víru lidí maximálně ještě několik let po pádu režimu. ${ }^{35}$ Život po roce 1990 také v ČR dobře prověril poznatek, že transmise náboženské víry mimo rodinu závisí do značné míry na společenském kontextu. ${ }^{36}$ Hypotéza o významnějším vlivu společenských a ekonomických podmínek na náboženskou socializaci potomků, než má rodičovské působení, se v tomto směru potvrdila. Trend započatý v severní a západní Evropě v padesátých letech 20 . století, spojený s plynule se vytrácejícím vlivem křestanské tradice a nárůstem posttradiční spirituality v posledních desetiletích, ${ }^{37}$ se projevuje i u nás jako důsledek existující společenské situace.

Odborníci si kladou otázku, proč je náboženská výchova ve většině případů málo efektivní. Odpovědi nacházejí $\mathrm{v}$ analýze vzájemného působení subjektivních i objektivních podmínek. Pohled na rodičovskou náboženskou výchovu ukazuje na několik typických obecných rysů: a) vliv rodičů je nepř́mýs ${ }^{38}$, b) náboženská socializace směřuje spíše $k$ reprodukci než ke zvyšování religiozity, c) z hlediska náboženské socializace nejsou zaznamenány rozdíly ve vlivu rodičů na děti v nábožensky orientovaných a sekularizovaných zemích ${ }^{39}$. Je možné, že dlouhodobý efekt náboženské výchovy směřovaný na mladé lidi je oslabený sociokulturním rozvojem na makroúrovni. ${ }^{40} \mathrm{~K}$ tomu se přidává i okolnost, že psychologická potřeba obracet se k náboženství v situaci zlepšování životních podmínek klesá a role náboženské socializace v rámci rodiny se stává náročnějšši. ${ }^{41}$ Mladí jsou méně náboženští než starší, a to u nás i ve světě. Jde o odraz historických změn souvisejících spíše s vyšší úrovní lidského rozvoje než s něčím, co se spojuje s cyklem lidského života. ${ }^{42}$ Plné pochopení náboženského socializačního procesu vyžaduje věnovat pozornost oběma úrovním, mikro i makro rovině, a jejich vzájemnému ovlivňování. Socializační proces není možné studovat nezávisle na sociálním kontextu. Na náboženské a nenáboženské socializaci se podílejí jak rodičovská náboženská socializace, tak další faktory zahrnující širší prostředí i společnost v minulosti i dnes.

35 Srov. např. KELLEY, National Context..., s. 295-314.

36 Srov. např. MÜLLER - SCHMIDT - DE GRAFF, Which Societies..., s. 739-759.

37 Srov. např. Dick HOUTMAN - Stef AUPERS, The Spiritual turn and the decline of tradition: the spread of Post-Christian spirituality of fourteen Western countries, Journal for the Scientific Study of Religion 3/ 2007, s. 305-320.

38 Srov. např. Kent JENNINGS - Laura STOCKER - Jake BOWERS, Politics Across Generations: Family Transmission Reexamined, The Journal of Politics 3/2009, s. 782-799.

39 Srov. např. STORM -VOAS, The Intergenerational..., s. 131-150.

40 Srov. napr. Paul VERMEER - Peer SCHEEPERS, Religious Socialization and Non-Religious Volunteering: A Dutch Panel Study, Voluntas 23/2012, s. 940-958.

41 Srov. např. MÜLLER - SCHMIDT - DE GRAFF, Which Societies..., s. 739-759.

42 Srov. např. Pippa NORRIS - Ronald INGLEHART, Sacred and Secular: Religion and Politics Worldwide, New York: Cambridge University Press, 2004 


\title{
Rozdíly v náboženské socializaci napříč generacemi
}

\begin{abstract}
Abstrakt
Náboženská socializace je $v$ centru pozornosti celé řady zahraničních autorů. Ve svých analýzách využívají kromě domácích výzkumných dat i údaje za národní celky získané z mezinárodního datového souboru International Social Survey Programme (ISSP) 2008: Religion III. Tématika náboženské socializace začíná poutat pozornost i v rámci českého odborného diskurzu. Článek navazuje na dosavadní prístupy a soustřed'uje se na okolnosti náboženské socializace v ČR. Zabývá se mírou intergeneračního přenosu náboženských představ. Cílem je posouzení podoby náboženského světonázoru v rámci hlavních věkových skupin české populace a jejich rodičů. Při interpretaci poznatků byly využity výsledky reprezentativního šetření realizovaného v prosinci 2015 až lednu 2016 na populaci ČR 15leté a starší v rozsahu 522 respondentů. Získaná data umožnila porovnání posunů v oblasti víry v Boha od roku 1991.
\end{abstract}

\section{Klíčová slova}

Náboženská socializace, osobní víra v Boha, víra rodičů, generace, spiritualita

\section{Kontakt}

\section{RSDr. Ján Mišovič, CSc.}

Jihočeská univerzita České Budějovice

Teologická fakulta, Katedra etiky, psychologie a charitativní práce Kněžská 8, 37001 České Budějovice

misovic@tf.jcu.cz 